\title{
PERFORMANCE ANALYSIS AND EXCESS AIR OPTIMIZATION IN FUEL COMBUSTION OF 210 MW BOILER
}

Sivakumar. $A^{1}$

\begin{abstract}
Power is the important source for any country's development. In India around sixty four percentage of power is generated from Thermal power station. Fossil fuels like coal, oil are mainly used in Thermal power plants. A study was conducted in Mettur Thermal Power plant for analyzing the performance of the $210 \mathrm{MW}$ Boiler. The designed efficiency of the boiler slightly varies with the calculated efficiency because of various reasons, among that unburned fuel is the important one. To enhance the boiler efficiency, excess air was supplied to avoid the unburned fuel. A study was conducted by varying the percentage of excess air from $10 \%$ to $31 \%$ with the interval of $3 \%$ and the efficiency of the boiler is calculated. The excess air quantity is optimized.
\end{abstract}

Keywords-Thermal Power, Unburned Fuel, Excess Air

\section{INTRODUCTION}

The Metter thermal power station is the first inland thermal power station of Tamil Nadu Electricity Board. It is situated at an altitude of 213 meter above the Mean Sea Level (MSL). Although there are two Hydro Power stations of capacities 40 MW \& 200 MW in existence, to increase the generating capacity of Tamil Nadu, this Thermal power station was proposed at Mettur, where Cauvery water is available for its use.

The boiler offered in Mettur Thermal Power Station is with the following specification.

- $\quad$ Single drum double pass unit

- Natural circulation

- Water tube boiler

- $\quad$ Tangential firing / corner firing system

- $\quad$ Balanced draft

- $\quad$ Dry bottom furnace.

- $\quad 700$ Tones of steam / Hour

- $\quad$ Temperature of steam $540^{\circ} \mathrm{C}$

- $\quad$ Pressure of steam $138 \mathrm{~kg} / \mathrm{cm}^{2}$

- Generation capacity $210 \mathrm{Mw}$

\footnotetext{
${ }^{1}$ Department of Mechanical Engineering Varuvan Vadivelan Institute of Technology, Dharmapuri, Tamil Nadu
} 
- $\quad$ Fuel required 3500 Tonnes/day

\section{II.BOILER PERFORMANCE OPTIMIZATION}

From the Boiler heat balance analysis the total amount of coal wasted due to excessive losses in the boiler is approximately 182 Tonnes / day.

The essence of boiler performance optimization is to the combustion / fireside reaction, such that a closed approach to stoichiometric combustion. The boiler performance optimization depends upon the following:

1. Unburned carbon in bottom and fly ash

2. Unburned ' $\mathrm{CO}$ ' in exit flue gas

3. Number of tube failures

4. Super heater and re- heater stagnation temperature

5. Exit gas temperature

6. Effective utilization of waste or unutilized water \& steam wherever possible.

The objective of the proposed boiler performance optimization effect is

1. The delineate the effect of reducing the excess air \& exit gas temperature on the various part of the boiler system.

2. To identify the physical mechanisms (combustion).

3. To develop the means of optimum selection of excess air level.

\section{OPTIMIZATION PARAMETER \& TECHNIQUES}

The parameter to be optimized based on the above methodology for optimizing the boiler performance is classified as follows:

Fuel related $\quad: \quad$ Particle fineness

Combustion related $\quad: \quad$ Excess air

Flue gas related $\quad: \quad$ Exit gas temperature of Air Pre - heater

Feed water related $\quad$ : $\quad$ Blow down value losses.

The techniques of optimizing the boiler performance are aimed at the following:

1. Minimizing waste heat $\&$ heat losses

2. Maximizing heat transfer

3. Minimizing auxiliary consumption

4. Maximizing the availability

5. Minimizing oil consumption

Optimization of coal fineness and excess air can produce restrictions in the plant's auxiliary power consumption and improve thermal efficiency, but there may be undesired side effects. Reduced coal fineness will also increase unburned carbon in the fly ash, and may increase the furnace slugging potential.

\section{LOSSES IN BOILER}

The efficiency of boiler is the ratio of heat absorbed by the fluid to the total heat supplied to the boiler. The heat utilized by fluid can be increases where by ensuring efficiency improvement. The following losses, which influence Excess air loss, are:

1. Dry flue gas loss 
2. Moisture loss

3. Unburned combustible loss

4. Blow down loss

5. Radiation loss

6. Unaccounted loss

Dry flue gas loss-This loss contributes a large proportion of the losses incurred in the boiler. It is due to the residual thermal energy constrained in the dry flue gas when its temperature is too low for further useful work. This loss is calculated as a function of the quantity of dry combustion gases, the temperature rise between Forced Draft fan inlet and the gas exit temperature, and the mean specific heat of flue gas at constant pressure.

Thus the loss can be influenced by any of this factor. However the quantity of excess air has the greatest influence because this causes deviation in both the weight of the flue gas and the final temperature. A change in the excess air quantity of $5 \%$ will change the loss by $\pm 1 \%$. The assessment of the specific heat of the flue gases is variable but dependent upon the $\mathrm{SO}_{2}$ content of the gas.

Dry gas loss $=\frac{\text { Dry gas } \times \text { 5perific beat of drygas } \times \text { (Tenperature of dry gas leaving-Amient temperature) }}{\text { Gross Caiorific value of fuel }}$

Moisture loss-The total moisture loss is the thermal energy in the water vapour entrained in the flue gases leaving the boiler. The water becomes super heated steam if the exit gas temperature is above dew point at the stack base.

The total moisture loss is made up of water derived from three sources.

1. The sum of free and inherent moisture in the fuel as fired. (The moisture flashes off into super heated steam in the furnace)

2. The products of the combustion of Hydrogen.

3. The moisture in the air for combustion includes excess air.

Loss due to moisture and hydrogen in the fuel $=\frac{\text { Twal moisture sheat ptr kg of mosturz }}{\text { Gross ralorific vaiue of fuel }}$

Loss due to air moisture $=($ Total dry air) $\mathrm{x}$ (mass of water vapour per $\mathrm{kg}$. of air) $\mathrm{x}$ (Temperature difference of

gas and air)

Unburned Combustible Loss (Mechanical Loss)-The main source of unburned fuel is carbon either in the bottom ash in the furnace hopper or that entrained by the flue gases flowing to the mechanical dust collector. The distribution ash is assumed to be $90 \%$ fly ash and $10 \%$ bottom ash. The calorific value of the combustible is normally taken to be that of carbon, i.e., $8077.8 \mathrm{Kcal} / \mathrm{kg}$. Losses are due to incomplete combustion of Carbon in fuel.

Loss due to Combustibles $=\frac{\text { Total combuatible in ash xilorific value of carbon }}{\text { Grass ralorific wave of fuel }}$

Loss due to sensible heat in fly ash and bottom ash - This is calculated by the following formula

Fly ash sensible heat $=\frac{\text { Fy shh } x \text { sperific heat of ash } x(\text { Temperature of gas leaving }- \text { Ambien: temperature })}{\text { Grosu Calorific value }}$ 
Bottom ash sensible heat =

Butom ashxpecific heat of ash x(Temperature of bottom ash -Anbient temperature)

Grosg Calorific walue

Radiation Loss-The loss due to radiation is normally taken from design standard of the boiler. This varies from $0.25 \%$ to $1.0 \%$

\section{PERFORMANCE CALCULATIONS OF BOILER UNIT}

The performance of a unit can be evaluated by calculating the overall efficiency of the unit (or) by calculating the individual efficiencies of the boiler, turbine and generator. The efficiency of the boiler is evaluated by the direct method or indirect method. In direct method, the output (steam) and input (coal/oil) are measured and the ratio of output/ input in terms of heat values is called boiler efficiency.

In the indirect method the input is assumed to be $100 \%$ and various losses encountered in the boiler are calculated and subtracted from 100.

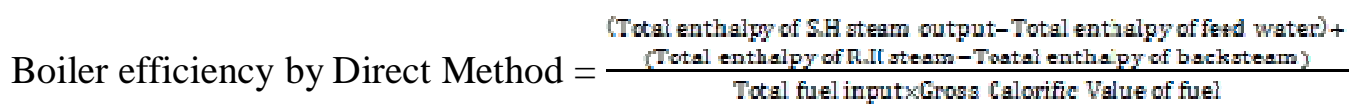

The direct calculation of boiler efficiency may turn out to be insufficiently accurate and involve difficulties in accurate measurement of mass flow rates of steam and fuel and also heating value of fuel.

In the Indirect Method, the boiler efficiency is calculated based upon the following losses in the boiler.

- $\quad$ Losses due to flue gas

- $\quad$ Losses due to Moisture and Hydrogen in fuel

- $\quad$ Radiation losses

\section{PARAMETERS OBSERVED}

The parameters observed during the power generation are listed in table 1 and 2 Table - 1 Coal Analysis

\begin{tabular}{|c|c|c|c|}
\hline \multicolumn{2}{|l|}{ Proximate Analysis of Coal } & \multicolumn{2}{|c|}{ Ultimate Analysis of Coal } \\
\hline$\%$ of Moisture & $6.05 \%$ & Ash & $44.7 \%$ \\
\hline$\%$ of Ash & $42.66 \%$ & Carbon & $36.9 \%$ \\
\hline$\%$ of Volatile Matter & $24.12 \%$ & Oxygen & $8.18 \%$ \\
\hline \multirow{2}{*}{$\%$ of Fixed carbon } & \multirow{2}{*}{$27.17 \%$} & Nitrogen & $0.7 \%$ \\
\hline & & Hydrogen & $3.02 \%$ \\
\hline \multirow{2}{*}{$\begin{array}{l}\text { Gross Calorific value of } \\
\text { fuel }\end{array}$} & \multirow{2}{*}{$\begin{array}{l}3660 \quad \mathrm{Kcal} / \\
\mathrm{Kg}\end{array}$} & Sulphur & $0.4 \%$ \\
\hline & & Moisture & $6.1 \%$ \\
\hline
\end{tabular}


Table - 2 Parameters observed

\begin{tabular}{|c|c|c|}
\hline S.No & Parameter & Data \\
\hline 1 & Feed Water( Mw) & 654 Tonne/hr \\
\hline 2 & Main System flow to H.P Turbine(Ms) & 640 Tonne/hr \\
\hline 3 & Steam flow in R.H(Msr) & 620 Tonne/hr \\
\hline 4 & Coal Burned(Mass of fuel) & 143 Tonne/hr \\
\hline 5 & Primary Air supply(Mpa) & 281 Tonne/hr \\
\hline 6 & Secondary Air supply & 653 Tonne/hr \\
\hline 7 & Drum Pressure & $146.3 \mathrm{Kg} / \mathrm{cm}^{2}$ \\
\hline 8 & Feed water pressure & $154.9 \mathrm{Kg} / \mathrm{cm}^{2}$ \\
\hline 9 & Inlet pressure in HP turbine & $136.3 \mathrm{Kg} / \mathrm{cm}^{2}$ \\
\hline 10 & Outlet pressure from HP turbine & $26.35 \mathrm{Kg} / \mathrm{cm}^{2}$ \\
\hline 11 & Re-heater inlet pressure & $26.35 \mathrm{Kg} / \mathrm{cm}^{2}$ \\
\hline 12 & Re-heater outlet pressure & $24.55 \mathrm{Kg} / \mathrm{cm}^{2}$ \\
\hline 13 & Feed water temperature Economizer inlet & $247: \mathrm{C}$ \\
\hline 14 & Temp. of Steam at HP turbine inlet & $540^{\circ} \mathrm{C}$ \\
\hline 15 & Temp. of Steam at RH inlet & $330^{\circ} \mathrm{C}$ \\
\hline 16 & Temp. of Steam at RH outlet & $540^{\circ} \mathrm{C}$ \\
\hline 17 & Saturated steam temp. at Drum & $341=\mathrm{C}$ \\
\hline 18 & Flue gas Temp. at chimney & $163^{\circ} \mathrm{C}$ \\
\hline 19 & Air pre heater inlet Temp. & $30=\mathrm{C}$ \\
\hline 20 & Air pre heater outlet Temp. & $310^{\circ} \mathrm{C}$ \\
\hline 21 & $\%$ of $\mathrm{CO}_{2}$ in flue gas & $15.4 \%$ \\
\hline 22 & $\%$ of $\mathrm{O}_{2}$ in flue gas & $4.2 \%$ \\
\hline 23 & Average \% of combustible fuel in Fly Ash & $1.00 \%$ \\
\hline 24 & Average $\%$ of combustible fuel in Bottom Ash & $6.06 \%$ \\
\hline
\end{tabular}

\section{EXCESS AIR OPTIMIZATION}

On any boiler the art of achieving high efficiency combustion largely depends on supplying correct quantity of air at the right place. If too little air is supplied the fuel is not completely burnt. If too much air is supplied, heat is wasted by means of flue gas being carried to the stack in greatest quantities than normal. The only part of the air which takes part in combustion is Oxygen, the reminder being Nitrogen which is merely a percentage and very expensive gas because of the following:

1. It carries heat to the chimney

2. It requires more fan power

3. It leads to $\mathrm{NO}_{\mathrm{x}}$ pollution

Definition of excess air - During combustion the air supplied may not come into intimate contact with all the fuel particles. Therefore, there is an incomplete combustion.

i) If there is insufficient air, the Carbon present in the fuel will burn to $\mathrm{CO}$ and will liberate $10117 \mathrm{KJ} / \mathrm{Kg}$ of heat.

$\mathrm{C}+($ Insufficient air $)=\mathrm{CO}+$ Heat $(10117 \mathrm{KJ} / \mathrm{Kg})$. 
ii) If there is sufficient air, the Carbon will react with as much air it requires, burnt to $\mathrm{Co}_{2}$ and will liberate $33822 \mathrm{KJ} / \mathrm{Kg}$ of heat.

$\mathrm{C}+($ Sufficient air $)=\mathrm{Co}_{2}+$ Heat $(33822 \mathrm{KJ} / \mathrm{Kg})$.

If the Carbon is burned completely to $\mathrm{CO}_{2}$, then we have complete combustion.

The complete combustion of fuel is impossible because we cannot arrange for all of the air to be in the right place at the right time. Hence to ensure the complete combustion, excess air has to be supplied than the required air (theoretical)

Thus by supplying excess air we are able to achieve:

i) Complete combustion

ii) More heat release of $23000 \mathrm{KJ} / \mathrm{Kg}$.

In addition, the additional air supplied:

i) Prevents slugging in furnace

ii) Cooling of non-operating burners

iii) Meets the requirements of high super heat temperature

To have complete combustion with minimum excess air, the air supply has to be properly distributed.

\section{EFFECTS OF EXCESS AIR ON VARIOUS LOSSES}

Radiation Loss-The radiation loss does not alter with the air quantity provided. Unburned Carbon Loss-This loss diminishes as the quantity of excess air increases. However there will always be some un- burnt Carbon even with high excess air.

Stack Loss or Dry Gas Loss-This loss is due to heat carried by the flue gas through the chimney. Obviously the more gas that goes up the stack, more quantity of excess air is to increase the stack loss. Also the gas temperature leaving the boiler tends to increase with higher excess air.

Auxiliary power loss-As the increase in excess air leads to increase in flue gas to be handled by ID fan and also the flue gas in FD fan will be increased for the same draft. Hence, the auxiliary power loss will increases as the excess air supply increases.

Minimum air required for complete combustion is

$100 / 23\left(8 / 3 \mathrm{C}+8 \mathrm{H}_{2}+\mathrm{S}-\mathrm{O}_{2}\right)$

Where, $\mathrm{C}-\%$ of Carbon in fuel, $\mathrm{H}-\%$ of Hydrogen in fuel' $\mathrm{O}_{2}-\%$ of Oxygen in fuel's - $\%$ of Sulphur in fuel

\section{OPTIMIZATION STUDY}

To determine the optimum level of excess air for the $210 \mathrm{MW}$ boiler at full load, at normal operating condition.

Methodology

Test Conditions- Load 210 MW

Test Procedure-The test conditions are maintained in the unit for more than one hour till steady state is reached. The required readings and the samples are taken. The test is repeated for different values for excess air. The amount of excess air is varied by varying the load on the FD fan without changing the furnace draft. 
Data Collection

The data's of various parameters collected are:
a. Mass of fuel supplied
b. Dry flue gas temperature
c. Mass of primary air and secondary air supply

Samples taken
a. Flue gas sample at air pre-heater outlet
b. Coal sample from bottom ash hopper
c. Coal sample at feeder inlet before the start of the test
d. Mill coal sample

Table 3 Excess air optimization-boiler efficiency analysis

\begin{tabular}{|l|l|l|l|l|l|l|l|l|}
\hline \multirow{2}{*}{$\begin{array}{l}\text { Nature of losses due } \\
\text { to excess air }\end{array}$} & \multicolumn{2}{|l}{ \% of Excess air } \\
\cline { 2 - 11 } & $\mathbf{1 0 \%}$ & $\mathbf{1 3 \%}$ & $\mathbf{1 6 \%}$ & $\mathbf{1 9 \%}$ & $\mathbf{2 2 \%}$ & $\mathbf{2 5 \%}$ & $\mathbf{2 8 \%}$ & $\mathbf{3 1 \%}$ \\
\hline $\begin{array}{l}\text { \% loss due to dry Flue } \\
\text { gas }\end{array}$ & $\begin{array}{l}5.728 \\
4\end{array}$ & $\begin{array}{l}5.895 \\
4\end{array}$ & $\begin{array}{l}6.197 \\
1\end{array}$ & $\begin{array}{l}6.426 \\
8\end{array}$ & $\begin{array}{l}6.740 \\
4\end{array}$ & $\begin{array}{l}7.145 \\
9\end{array}$ & $\begin{array}{l}7.300 \\
3\end{array}$ & $\begin{array}{l}8.965 \\
2\end{array}$ \\
\hline $\begin{array}{l}\% \text { of loss due to } \\
\text { moisture and H2 in } \\
\text { fuel }\end{array}$ & $\begin{array}{l}5.685 \\
1\end{array}$ & $\begin{array}{l}5.666 \\
4\end{array}$ & $\begin{array}{l}5.687 \\
5\end{array}$ & $\begin{array}{l}5.681 \\
2\end{array}$ & 5.681 & $\begin{array}{l}5.698 \\
6\end{array}$ & $\begin{array}{l}5.681 \\
2\end{array}$ & 5.689 \\
\hline $\begin{array}{l}\text { \% of loss due to } \\
\text { unburned carbon in } \\
\text { Ash }\end{array}$ & $\begin{array}{l}2.869 \\
2\end{array}$ & $\begin{array}{l}2.427 \\
8\end{array}$ & $\begin{array}{l}2.184 \\
9\end{array}$ & $\begin{array}{l}1.875 \\
9\end{array}$ & $\begin{array}{l}1.655 \\
3\end{array}$ & $\begin{array}{l}1.324 \\
2\end{array}$ & $\begin{array}{l}1.147 \\
6\end{array}$ & 0.949 \\
\hline $\begin{array}{l}\% \text { of loss due to } \\
\text { sensible heat in ash }\end{array}$ & $\begin{array}{l}2.535 \\
2\end{array}$ & $\begin{array}{l}2.178 \\
7\end{array}$ & $\begin{array}{l}2.010 \\
4\end{array}$ & 1.767 & $\begin{array}{l}1.534 \\
6\end{array}$ & $\begin{array}{l}1.272 \\
7\end{array}$ & 1.1 & $\begin{array}{l}1.084 \\
1\end{array}$ \\
\hline $\begin{array}{l}\% \text { of loss due to } \\
\text { excess air }\end{array}$ & $\begin{array}{l}0.460 \\
5\end{array}$ & $\begin{array}{l}0.611 \\
5\end{array}$ & $\begin{array}{l}0.791 \\
2\end{array}$ & $\begin{array}{l}0.962 \\
9\end{array}$ & $\begin{array}{l}1.192 \\
9\end{array}$ & $\begin{array}{l}1.448 \\
2\end{array}$ & 1.648 & $\begin{array}{l}1.957 \\
8\end{array}$ \\
\hline $\begin{array}{l}\text { \% loss due to moisture } \\
\text { in air }\end{array}$ & $\begin{array}{l}1.211 \\
6\end{array}$ & $\begin{array}{l}2.131 \\
7\end{array}$ & $\begin{array}{l}2.653 \\
8\end{array}$ & $\begin{array}{l}0.156 \\
2\end{array}$ & 0.472 & $\begin{array}{l}0.579 \\
6\end{array}$ & $\begin{array}{l}0.607 \\
4\end{array}$ & 2.589 \\
\hline Boiler efficiency \% & $\mathbf{7 9 . 8}$ & $\mathbf{7 9 . 9 9}$ & $\mathbf{8 0 . 9}$ & $\mathbf{8 1 . 4 2}$ & $\mathbf{8 1 . 4 5}$ & $\mathbf{8 1 . 9 9}$ & $\mathbf{8 2 . 0 2}$ & $\mathbf{8 0 . 7}$ \\
\hline
\end{tabular}

\section{X.CONCLUSION}

The efficiency of the boiler is high with $28 \%$ of excess air. Increase in $\%$ of excess air leads to increase of heat loss in flue gases, thereby decreasing the percentage of boiler.

\section{REFERENCES}

[1] Thermal Engineering - Engineering Thermodynamics \& Energy Conversion Techniques P.L.Ballaney

[2] Thermal Science and Engineering-Dr. M.L.Mathur \& Prof. F.S.Mehta

[3] Thermal Engineering-R.K. Rajput

[4] Thermal Engineering-S.L. Somasundaram

[5] Thermal Engineering-Rathor, M Mahesh

[6] Steam and Gas turbine \&power Plant Engineering Dr. R.Yadav 